\title{
Modern technologies in working with gifted students
}

\section{Tecnologías modernas para trabajar con estudiantes con estudiantes superdotados}

\author{
Irina V. Rudenko
}

Togliatti State University, Togliatti, Russia.

ORCID: https://orcid.org/0000-0002-1395-4263

\section{Natalia V. Bystrova}

Minin Nizhny Novgorod State Pedagogical University, Nizhny Novgorod, Russia. ORCID: https://orcid.org/0000-0002-4310-6142

\section{Zhanna V. Smirnova}

Minin Nizhny Novgorod State Pedagogical University, Nizhny Novgorod, Russia. ORCID: https://orcid.org/0000-0001-9950-9824

\section{Olga I. Vaganova}

Minin Nizhny Novgorod State Pedagogical University, Nizhny Novgorod, Russia. ORCID: https://orcid.org/0000-0001-8347-484X

\section{Maxim M. Kutepov}

Minin Nizhny Novgorod State Pedagogical University, Nizhny Novgorod, Russia. ORCID: https://orcid.org/0000-0002-5397-6168

\section{*Correspondence}

Email: ivannovadremova29@gmail.com

\section{Cite as:}

Rudenko, I., Bystrova, N., Smirnova, Z., Vaganova, O., Kutepov, M. (2021). Modern technologies in working with gifted students. Propósitos y Representaciones, 9 (SPE1), e818. Doi: http://dx.doi.org/10.20511/pyr2021.v9nSPE1.818

(c) Universidad San Ignacio de Loyola, Vicerrectorado de Investigación, 2020. 


\section{Summary}

Intellectual potential acts as a driving force of social and economic development of the modern state. In a high-tech society, there is a significant increase in interest in identifying and implementing the intellectual abilities of young people. The purpose of the article is to review the experience of using modern educational technologies in working with gifted students. The paper explores the implementation of innovative technologies, including games, projects, and collaborative learning technologies. The use of project and game technologies allows to develop the creative potential of students, to form an experience of research and creative activity, to activate cognitive interest by combining theory and practice. Modern educational technologies expand the opportunities for the formation and development of children's giftedness. Giftedness is a high level of development of any abilities. They are a special resource that forms the basis of the country's competitiveness and potential, which is updated as socially significant in the context of the analysis of fundamental documents in the field of education. Educational technologies allow not only to have a purposeful educational impact on students but also to create a variable, enriched, individualized educational environment that promotes the development of independence and self-learning ability.

Keywords: educational technologies, gifted students, giftedness, project technologies, game technologies

\section{Resumen}

El potencial intelectual actúa como motor del desarrollo social y económico del Estado moderno. En una sociedad de alta tecnología, hay un aumento significativo en el interés por identificar e implementar las habilidades intelectuales de los jóvenes. El propósito del artículo es revisar la experiencia de usar tecnologías educativas modernas al trabajar con estudiantes superdotados. El documento explora la implementación de tecnologías innovadoras, incluidos juegos, proyectos y tecnologías de aprendizaje colaborativo. El uso de tecnologías de proyectos y juegos permite desarrollar el potencial creativo de los estudiantes, formar una experiencia de investigación y actividad creativa, activar el interés cognitivo combinando teoría y práctica. Las tecnologías educativas modernas amplían las oportunidades para la formación y el desarrollo de la superdotación de los niños. La superdotación es un alto nivel de desarrollo de cualquier habilidad. Son un recurso especial que forma la base de la competitividad y el potencial del país, que se actualiza como socialmente significativo en el contexto del análisis de documentos fundamentales en el campo de la educación. Las tecnologías educativas permiten no solo tener un impacto educativo significativo en los estudiantes, sino también crear un entorno educativo individualizado, enriquecido y variable que promueve el desarrollo de la independencia y la capacidad de autoaprendizaje.

Palabras clave: tecnologías educativas, estudiantes superdotados, superdotación, tecnologías de proyectos, tecnologías de juegos.

\section{Introduction}

Gifted youth represent a significant economic potential of the country. In the context of the analysis of fundamental documents in the field of education, this is a particularly significant social resource. Federal law" on education in the Russian Federation " No. 273FZ of 2012 sets the priority of creating conditions for the development of students, ensuring their self-determination through personally significant activities. The Federal state educational standard establishes the development of students' cognitive needs that go beyond traditional learning. The state program of the Russian Federation "Development of education" for 2018-2025 provides for the implementation of modern forms of organization for the development of students ' giftedness. Gifted children, as a rule, have a high level of self-learning ability, so there is not only a need for targeted educational actions, but also for creating a variable, enriched educational environment 
(Andrienko, 2019a). Among the innovative ways of developing giftedness, educational technologies that contribute to the guaranteed achievement of goals occupy a significant place (Blinova \& Blinova, 2010).

In the aspect of the issue under consideration, the works devoted to the development of the potential of a gifted student by O. A. Tolstopyatova, E. V. Bugakova, and V. I. Krasnova are of considerable interest. The conceptual basis for understanding the problems of General giftedness is considered by J. p. Blavatsky. Renzulli, N. N. Zhurba and others. G. I. Zhelezovskaya speaks in their works about the independent understanding of reality and the transformation of knowledge into the potential of thinking and independent development.

The giftedness of youth can be considered as a potential for mental development in relation to the subsequent stages of a person's life path (Andrienko, 2019b).

In the works of S. I. Osipova, A.V. Zakharova, E. V. Markelova and others, attention is paid to the influence of teachers on the development of gifted children in modern educational institutions. Some aspects of the development of gifted children are considered by S. A. Badoeva, E. E. Antonova, G. M. Anokhina and others.

The influence of educational technologies on the learning process of gifted children is presented in the works of E. M. Grigorieva, A. A. Zvereva and others. Taking into account the importance of existing research on the issue of working with gifted students, it should be said that today the topic of implementing modern technologies in the training of gifted children is not sufficiently studied (Andriushchenko, 2018).

Such scientists as Yu.d. Babayeva, L. S. Vygotsky, a.m. Matyushkin (Matyushkin \& Sisk, 1988 ) and others made a great contribution to the explanation of the essence, nature and structure of giftedness (Cirdan, 2019); (Filchenkova, 2019).

The concept of "giftedness", according to some authors, can include three components: the child's intelligence, creativity, and spirituality (Chertovskikh, 2019); (Donetskova, 2019). Spirituality means the ability of students to see and create beauty, possess a high level of morality, and be a part of society. Giftedness is a multidimensional and multi-level phenomenon (Grigoriev et al., 2019); (Oros, 2018). At the same time, the development of giftedness occurs only in activities that should be built by the teacher in such a way that students feel a positive emotional mood (Gladkov et al., 2019); (Klinkov, 2018). Teachers implement situations of success for children through the use of modern educational technologies (Bakharev, 2019). The main activities of students include:

- practical;

- theoretical (Aleksieienko-Lemovska, 2019);

- artistic and ethical;

- communicative;

- spiritual and valuable.

The spheres of the psyche are represented as intellectual, emotional, motivational and volitional (Ilyasov \& Selivanova, 2014); (Kotlyar, 2008). Within the intellectual sphere, sensorimotor, spatial-visual, and conceptual-logical levels are distinguished (Halatsyn \& Feshchuk, 2019); (Kobernyk et al., 2019). The emotional sphere is represented by the levels of emotional response and emotional experience. The motivational-volitional sphere includes the levels of motivation, goal setting and meaning generation (Linkov \& Klinkov, 2018); (Moskvina et al., 2019). According to these levels, there are types of giftedness:

- in practical activities, such as sports or organizational; 
- in cognitive activity-intellectual giftedness depending on the subject content of the activity (Osadchenko, 2019); (Prokhorova \& Semchenko, 2018);

- in artistic and aesthetic activity-stage, literary, visual, musical talent (Pliushch, 2018); (Pichugina \& Zhilyakova, 2019);

- in spiritual and value activity - giftedness, which is manifested in the creation of new spiritual values (Petrichev et al., 2018); (Tretyakov, 2019).

According to the degree of formation of giftedness, actual and potential giftedness are distinguished. Through the forms of manifestation of giftedness-explicit and hidden. According to the breadth of manifestations, there may be general mental giftedness and a special one (Raven, 1989).

Identification of children's giftedness is a rather difficult process, which is based on such principles as:

- comprehensive assessment of different aspects of the child's behavior and activity (Pisarenko, 2019);

- long-term observation of the behavior of a particular child in different situations (Tolkanuk, 2019);

- analysis of the student's behavior in areas of activity that correspond to their aptitudes and interests (use of game technologies, involvement in the implementation of a project) (Vaganova et al., 2019c); (Vaskovskaya et al., 2018);

- use of valid methods of psychodiagnostic (Tsarapkina et al., 2019b); (Vaganova et al., 2019b).

- Gifted students have a fairly high level of development of any abilities (Vaganova et al., 2019a); (Zhelezovskaya et al., 2006). To further develop these abilities, it is necessary to use modern tools. Innovative educational technologies will make the process of developing the abilities of gifted children more intensive and effective.

\section{Material and methods}

The study was conducted during the 2019-2020 academic year from May to September. It was attended by 70 students, regardless of gender. We have studied the impact of the implementation of modern educational technologies in the educational process on the development of students ' giftedness. We have identified control and experimental groups. In the experimental group, modern educational technologies were introduced to expand the training opportunities for students, create the necessary situations of success and include children in an active interaction process to achieve their goals. At each lesson, teachers used technologies that develop independence in the process of solving problem situations (Arbeláez-Campillo, \& RojasBahamon, 2020). The Fisher statistical criterion was used to compare the results of the control and experimental groups. It was chosen because it is based on an ordinal scale. The Fisher criterion takes into account the number of students who confirmed or did not confirm the increase in the level of development of giftedness. Several types of research methods were used to identify the level of giftedness:

- creative potential (T. V. Dembo and S. Ya. Rubinstein);

- the achievement motivation;

- socio-psychological adaptability, relations with the surrounding world (T. V. Snegireva);

- personal traits (R. Kettela).

Using the "gifted map" technique of Haan and Kaffa, a quantitative assessment of the degree of expression of various types of giftedness in a child is revealed and it is determined which type of giftedness prevails at a given time.

These types include: 
- intellectual;

- creative;

- academic;

- art;

- musical;

- literary;

- artistic;

- technical;

- leadership;

- sporty.

According to the method "map of giftedness" by A. I. Savenkov, the assessment of total giftedness is determined:

- curiosity;

- sensitivity to problems;

- the ability to predict the result;

- the amount of vocabulary;

- ability to evaluate;

- ingenuity;

- ability to think logically and reason;

- a manifestation of perseverance;

- perfectionism.

Determining the development of giftedness requires the use of several methods. The main goal of diagnostics is to ensure optimal conditions for realizing the potential of each child (Zakhlebny et al., 2007).

Table 1 shows the levels of development of students' giftedness.

Table 1.

Levels of development of students' giftedness.

\begin{tabular}{|l|l|}
\hline Level & Characteristic \\
\hline $\begin{array}{l}\text { Level of development special } \\
\text { skills }\end{array}$ & $\begin{array}{l}\text { A high level of self-learning abilities increased selective } \\
\text { sensitivity to certain aspects of objective reality (signs, colors, } \\
\text { sounds, technology and others), a willingness to go beyond } \\
\text { the requirements of a teacher to learn on their own initiative, } \\
\text { a vivid interest in certain areas of activity, high dedication to } \\
\text { either subject. }\end{array}$ \\
\hline $\begin{array}{l}\text { Level of academic success } \\
\text { (indicators of academic } \\
\text { achievement) }\end{array}$ & $\begin{array}{l}\text { The implementation of active activities in the learning } \\
\text { process, the operational solution of practical problems posed } \\
\text { by the teacher. Highly structured activities and the } \\
\text { assimilation of knowledge corresponding to the intellectual } \\
\text { orientation of the child. A realistic assessment of yourself and } \\
\text { your own achievements. High speed and ease of training. The } \\
\text { ability for effective research activities. The ability to } \\
\text { implement their own ideas manifested in the artistic, literary, } \\
\text { sports and other activities. The ability to implement their own } \\
\text { ideas and protect their ideas. }\end{array}$ \\
\hline
\end{tabular}


Level of development of general intelligence
Children show great perseverance and hard work. They are demanding the results of their own work, prone to set difficult goals and perfectionism. The child asks a lot of questions on topics of interest to him, shows the ability to explain the meaning of leading concepts. Tools for the implementation of active educational activities.

\section{Results}

Creating psychological conditions for teachers to solve specific pedagogical tasks allows them to develop the potential of students. The main structural components of giftedness correspond to the basic principles of creativity:

- the leading role belongs to cognitive motivation;

- research and creative activity is reflected in the discovery of a new, the formulation and solution of emerging problems;

- achievement of original solutions;

- the ability to predict.

The success of creative self-realization in the development of giftedness plays a big role. The use of educational technologies allows children to expand their opportunities for selfrealization.

The use of various educational technologies allows you to include each student in an active independent activity, in which each child performs its function and can realize itself.

In the course of training, we implemented project technologies, game technologies, technologies of problem-based learning, training in collaboration, and others. All tasks contain a problem that needs to be solved (Pinkovetskaia et al, 2020). Children are divided into subgroups and together try to find a solution to their tasks. The project activity of students is carried out in several stages. At the first stage, the teacher helps children identify the facts and circumstances associated with the cause of the problem, as well as discuss preliminary ways out of the situation. At the next stage, activities are built between students and the teacher in the direction of solving the problem. Functions are distributed among the participants in the process. The teacher encourages the independent actions of students. The third stage is a reflection of the work done. A joint discussion of the child and the teacher's successes and failures allows you to highlight key points that confirm the correctness or error of the designed actions. The teacher creates conditions in which the student is able to independently analyze their actions, evaluate the results achieved. Various creative games were also used in the training process. They develop originality, unconventional thinking, and the ability to look at the situation from different angles. In the course of playing activities, children performed tasks that allowed them to expand, add, and continue the original idea. Students strive to come up with as many ideas as possible. Games allow you to develop the imagination of children, to identify the features of various phenomena. For example, the game "What would I do if..." allows you to unlock the creative potential of students. The teacher divides children into subgroups of 5-7 people and sets a specific situation for each subgroup. Children should come up with a story about their situation. For example, "What would I do if... if I needed to organize a campaign", "What would I do if I became President", "What would I do if I needed to set up a garden or vegetable garden". Tasks vary depending on the age of the participants, so for some groups, they look like "What would I do if I became a wizard" or "What would I do if I had a magic wand".

The results of research in terms of tracking the level of development of giftedness in the control and experimental groups are systematized in the table below. 
Table 2.

The results of statistical processing of data to identify the level of development of giftedness of the control and experimental groups.

\begin{tabular}{|c|c|c|c|c|}
\hline \multirow[t]{2}{*}{ Level } & \multicolumn{2}{|c|}{$\begin{array}{l}\text { Control group (\% of total } \\
\text { participants) }\end{array}$} & \multicolumn{2}{|c|}{$\begin{array}{l}\text { Experimental group (\% of total } \\
\text { participants) }\end{array}$} \\
\hline & $\begin{array}{l}\text { At the beginning } \\
\text { of the study }\end{array}$ & $\begin{array}{l}\text { At the end of the } \\
\text { study }\end{array}$ & $\begin{array}{l}\text { At the beginning of } \\
\text { the study }\end{array}$ & $\begin{array}{l}\text { At the end of the } \\
\text { study }\end{array}$ \\
\hline $\begin{array}{l}\text { Level of } \\
\text { development } \\
\text { of special } \\
\text { skills }\end{array}$ & $30 \%$ & $31 \%$ & $30 \%$ & $37 \%$ \\
\hline $\begin{array}{l}\text { Level of } \\
\text { academic } \\
\text { success } \\
\text { (indicators of } \\
\text { academic } \\
\text { achievement) }\end{array}$ & $35 \%$ & $37 \%$ & $36 \%$ & $40 \%$ \\
\hline $\begin{array}{l}\text { Level of } \\
\text { general } \\
\text { intelligence } \\
\text { development }\end{array}$ & $25 \%$ & $26 \%$ & $24 \%$ & $35 \%$ \\
\hline
\end{tabular}

We can see that at the end of the study in the experimental group, the level of development of gifted and changed for the better. Children became more interested in cognitive activity, the motivation for learning and deepening their knowledge increased. Design and gaming technologies have enabled children to become more interested in specific activities. Figure 1 shows the results of a study of the general giftedness of students.

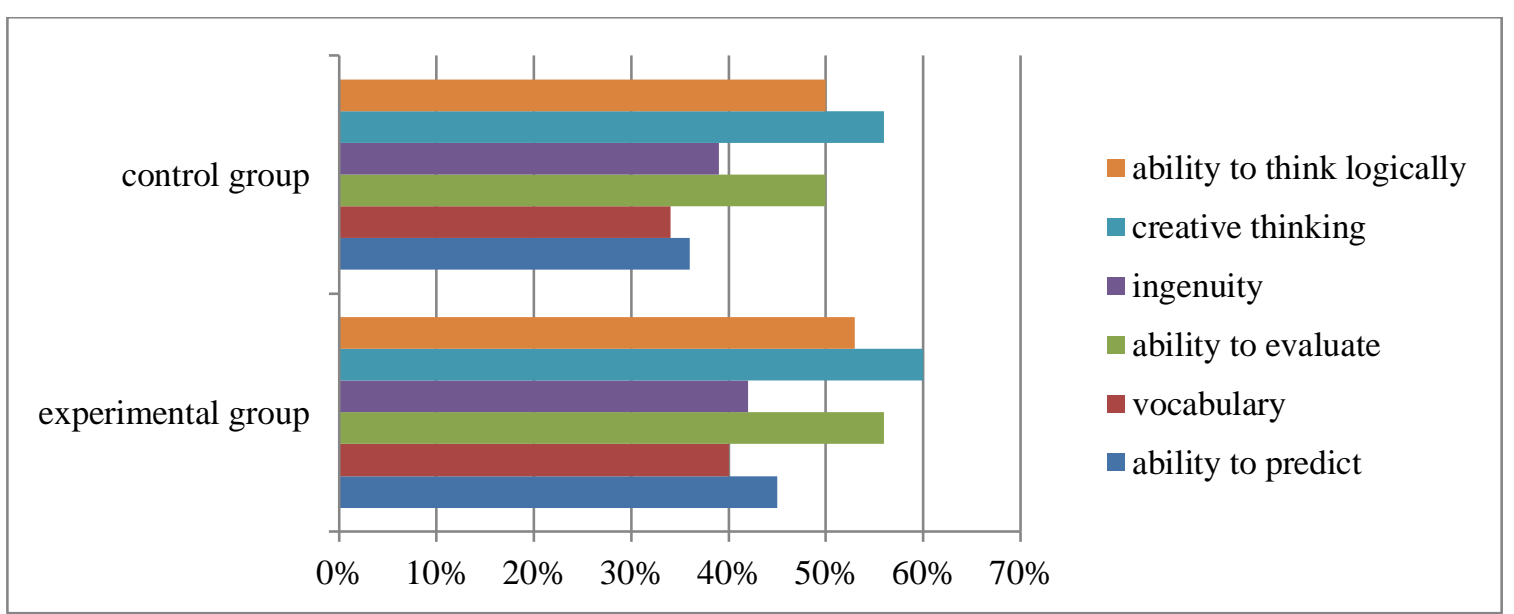

Fig. 1. The results of statistical processing of data of identifying the general students' giftedness.

The results show that the percentage of children who have mastered the ability to think logically and predict has increased. The participants in the experimental group became more inventive. Their vocabulary has expanded and their ability to evaluate their own work and that of other children has increased. In General, the level of General giftedness of children in the experimental group increased. 


\section{Discussion}

The analysis of the research results allowed us to establish that students form the ability not only to carry out practical activities but also develop motivation for the development of their own giftedness, learning reflection - critical attitude to the activity and future self-realization in it. Students of the experimental group demonstrated the ability to actively interact with friends and teachers. They showed an increase in literary, artistic, and sporting skills, a steady interest in activities, and the ability to set goals for the use and acquisition of new knowledge.

The implementation of modern educational technologies in the development of gifted children allows them to constructively perceive criticism, act in unstructured conditions and protect their own interests, visualize and build mental images, and search for alternatives.

\section{Limitations}

The results of the presented experiment are limited to a sample of study participants. The study within the limited sample of students does not allow to cover the entire focus group of young people. For the further more reliable collection of statistical data, it is necessary to implement a comparative analysis of a more reliable sample.

\section{Conclusion}

We reviewed the experience of using modern educational technologies in working with gifted students. The study showed that the integrated use of modern educational technologies contributes to the development of children's giftedness in various fields. It allows you to organize active interaction between teachers and students, develop children's independence, critical thinking, and motivation to learn.

Acknowledgments: The authors sincerely thank the participants in the experiment who took part in this study.

\section{References}

Aleksieienko-Lemovska, L.V. (2019). The activity approach as a basis for preschool teachers' methodological activities, Humanitarian Balkan Research, 3, 4(6), 10-14.

Andrienko, O.A. (2019a). On the need to apply gaming training technologies. Balkan Scientific Review, 2 (4), 5-8.

Andrienko, O.A. (2019b). Modern educational technologies: technology of self-presentation. Balkan Scientific Review, 1(3), 5-7.

Andriushchenko, T. K. (2018). Personal aspects of pedagogue's innovative culture. Scientific Vector of the Balkans, 1, 13-16.

Arbeláez-Campillo, D.F., \& Rojas-Bahamon, M.J (2020). "Pandemics in globalization times". Amazonia Investiga, 9(27), 3-4. https://amazoniainvestiga.info/index.php/amazonia/article/view/1189

Bakharev, N. P., (2019). Creativity - a prerequisite for the formation of professional competences in specialists of technical direction of training. Scientific Vector of the Balkans, 3, 4 (6), $17-21$. 
Blinova, V. L., \& Blinova, L.F. (2010). Children's giftedness: theory and practice: textbook. method. benefits. Kazan: TSPPU, 56.

Chertovskikh, O.O. (2019). Prospects for the use of digital resources in education. Baltic Humanitarian Journal. 8, 4 (29), 184-187.

Cirdan, A.P. (2019). Innovative technologies of professional training of future economists in the system of continuous education. Humanitarian Balkan Research, 2(4), 27-30.

Donetskova, O.YU. (2019). Modernization of the modern education system in Russia. Baltic Humanitarian Journal, 8, 2 (27), 37-39.

Filchenkova, I.F. (2019). Educational management of innovative activity of teachers as an object of pedagogical research. Vestnik of Minin University, 2019.7 (4), 3.

Gladkov, A.V., Vaganova, O.I., \& Prokhorova, M.P. (2019). Modern pedagogical technologies as a means of enhancing educational motivation. Baltic Humanitarian Journal. 8, 1 (26). 274-276.

Grigoriev S. G., Shabunina V. A., Tsarapkina Ju. M., \& Dunaeva N. V. (2019). Electronic library system as a means of self-development of students of digital generation $\mathrm{Z}$ (on the example of studying the course "Basics of the counselor activity"). Scientific and technical libraries. 7, 78-99. 29.

Halatsyn, K.A., \& Feshchuk, A.M. (2019). Diagnosing motivational-and-valuable component of the communicative culture of students in higher technical educational institutions. Balkan Scientific Review, 3, 2 (4), 17-20.

Ilyasov, D. F., \& Selivanova, E. A. (2014). Psychological and pedagogical support of the gifted high school students in a competitive test situation. Fundamental research. 12, 11, 174178.

Klinkov, G.T. (2018). The specificity of manifestation of pedagogical communication as a special construct. Scientific Vector of the Balkans, 1, 51-52.

Kobernyk, O.M., Stetsenko, N.M., Boichenko, V.V., \& Pryshchepa, S.M. (2018). Improving professional and pedagogical training of future teachers by moodle platforms (On the example of the course "Pedagogy"). Scientific Vector of the Balkans, 1, 5-7.

Kotlyar, I.A. (2008). About the early studies of L.I. Bozhovich. Modern problems of personality psychology: theory and practice.

Linkov, A.Y., \& Klinkov, G.T. (2018). Person-oriented learning based on its sociological derivation. Scientific Vector of the Balkans, 1, 5-7.

Matyushkin, A.M., \& Sisk, D.N. (1988). Gifted and talented children. Questions of psychology. 2.

Moskvina, A. S., Bykovskaya, T. E., Panteleeva, N. G., Balabas, N. N., \& Tretyakov, A. L. (2019). Features of the implementation of the content of environmental education in the context of a preschool educational organization. Prospects of Science and Education, 41 (5), 271288.

Oros, I.I. (2018) The role of international connections in the development of the adult education system. Humanitarian Balkan Research, 1, 57-59. 
Osadchenko, I.I. (2019). Key concepts of situational training technology in preparing future teachers. Scientific Vector of the Balkans, 1 (3), 46-49.

Petrichev, P. V., Masyuk, N. N., \& Bushueva, M. A. (2018). Method of estimation of the effectiveness of the partnership russian universities with foreign educational organizations. Azimuth of Scientific Researches: Economics and Management, 7, 3 (24), 229-232.

Pichugina, G. A., \& Zhilyakova, D. A. (2019) Structuring the organization of the process of creativity. Scientific Vector of the Balkans, 3, 3 (5), 55-58.

Pinkovetskaia, I.S, Arbeláez-Campillo, D.F., Rojas-Bahamón, M.J., \& Veas Iniesta. D. (2020). "Motivation of new entrepreneurs in modern economies" Amazonia Investiga, 9(29), 368373. https://amazoniainvestiga.info/index.php/amazonia/article/view/1403

Pisarenko, D. A. (2019). Evaluation of extracurricular activities of university students with a competency-based approach, Scientific Vector of the Balkans, 3, 3 (5), 37-40.

Pliushch, V.M. (2018). Independent work of students as a factor of improving education quality. Balkan Scientific Review, 1, 69-71.

Prokhorova, M.P., \& Semchenko, A.A. (2018). Involving of trainees-future teachers of professional training in project activities in the discipline. Vestnik of Minin University, 6, (2), 6. DOI: 10.26795/2307-1281-2018-6-2-6.

Raven, S. N. (1989). Formation of ecological concepts of schoolchildren through the use of the analogy method (on the example of studying the ecosystem of the cosmos). Fundamentals of General psychology. - M.: Pedagogy, 488.

Tolkanuk, Z. A. (2019). Professional self-determination of youth as a factor of training of a competent specialist, Balkan Scientific Review, 3, 2 (4), 57-59.

Tretyakov, A. L. (2019). Ecological education of preschool children: statement of the problem. Language and urgent problems of education: scientific papers of the IV International Scientific and Practical Conference, 317-321. (In Russ.)

Tsarapkina, Ju. M., Dunaeva, N. V., \& Kireicheva, A. M. (2019b). Application of BYOD technology in education on the example of Lecture Racing mobile application. Informatics and Education, 9 (308), 56-64.

Tsarapkina, Ju.M., Petrova, M.M., Mironov, A.G., Morozova, I.M., \& Shustova, O.B. (2019a). Robotics as a basis for Informatization of education in children's health camp. Amazonia $\begin{array}{llll}\text { Investiga, } & 8 & \text { (20). }\end{array}$ https://www.amazoniainvestiga.info/index.php/amazonia/article/view/70

Vaganova, O.I., Ilyashenko, L.I., Smirnova, Zh.V., Bystrova, N.V., \& Kaznacheeva, S.N. (2019a). Students' creative abilities development in higher educational institution. Amazonia $\begin{array}{llll}\text { Investiga, } & 8 & \text { (22), }\end{array}$ https://www.amazoniainvestiga.info/index.php/amazonia/article/view/822

Vaganova, O.I., Livshits, Yu.A., Aleshugina, E.A., Smirnova, Zh.V., \& Kutepova, L.I. (2019c). Experience in developing electronic glossary in a higher education institution. Amazonia Investiga, 8 (22), https://www.amazoniainvestiga.info/index.php/amazonia/article/view/421 
Vaganova, O.I., Rudenko, I.V., Markova, S.M., Smirnova, Zh.V., \& Kutepov, M.M. (2019b). The use of educational video materials in educational process of a higher educational institution. Amazonia Investiga, 8 (22), 216-222. https://www.amazoniainvestiga.info/index.php/amazonia/article/view/308

Vaskovskaya, G.A. (2018). Features of implementation of pedagogical technologies of profile training. Balkan Scientific Review, 1, 76-79.

Zakhlebny, A. N., \& Dzyatkovskaya, E. N. (2007). Ecological competence - a new planned result of environmental education, Environmental education: before school, at school, outside of school, 3, 3-8.

Zhelezovskaya, G.I. (2006). Problems and prospects for the development of continuing professional education in the era of social reforms, Scientific book, 1, 303, 297. 